\title{
School Building Defects: Impacts Teaching and Learning Environment
}

\author{
Norsafiah Norazman, Siti Nurul Asma' Mohd Nashruddin, Adi Irfan Che Ani, Norhaslina \\ Jaa'far, Muhamad Azry Khoiry
}

\begin{abstract}
This paper focus point is common building defects that usually give result instead of the negative impacts on the teaching and learning environment school buildings in Malaysia. An overview of common defects is involved in the school building, which will facilitate a comparative school building performance. The study stated the failure to control the critical defects in the school building and then concluded that they are affecting the teaching and learning environment. Thus, this study aimed to identify the building defects that commonly happen in school buildings in Malaysia. Next, identified the critical elements of school building involved in defects. It also analyzed the effect of school building defects towards the teaching and learning environment. A literature review was conducted to analysis the common building defects involved at the school building. Beside, this paper reviewed, summarized, and discussed the common building defects that usually happen in the school buildings and the effect to the teaching and learning environment. The survey instruments used in this study were random questionnaire distribution to fifty (50) respondents and interview with ten (10) teachers. The findings had shown that major defects in the school buildings are peeling paint, dampness, and cracked wall. The finding revealed that school building defects mostly affected students' concentration and attendance where it found from the majority of interview participants, thereby giving a direct impact on the environment of teaching and learning. This paper provides the current information, knowledge and findings that related with common types of school building defects that may affect students' performance. Therefore, it will assist the school building management, building facilities and other professionals to clarify the specific building defects more early based on the current findings.
\end{abstract}

Keywords: Building Defects, Environmental, Facilities, Learning Space, School Condition

Revised Manuscript Received on June 22, 2019.

Norsafiah Norazman, Department of Architecture, Faculty of Engineering and Built Environment, Universiti Kebangsaan Malaysia, Bangi 43600 Malaysia

Siti Nurul Asma' Mohd Nashruddin, Department of Architecture, Faculty of Engineering and Built Environment, Universiti Kebangsaan Malaysia, Bangi 43600 Malaysia

Adi Irfan Che Ani, Department of Architecture, Faculty of Engineering and Built Environment, Universiti Kebangsaan Malaysia, Bangi 43600 Malaysia

Norhaslina Jaa'far, Department of Architecture, Faculty of Engineering and Built Environment, Universiti Kebangsaan Malaysia, Bangi 43600 Malaysia

Muhamad Azry Khoiry, Department of Civil \& Structural, Faculty of Engineering and Built Environment, Universiti Kebangsaan Malaysia, Bangi 43600 Malaysia

\section{INTRODUCTION}

School buildings are the environment in which the teaching and learning process unfolds among teachers and students. The condition of a school building is more correlated to student performance than other influential factors such as family background, socioeconomic status or financial, school attendance, and behaviour. On the other hand, National Clearinghouse for Educational Facilities also found out that poor condition of school facilities will affect academic achievement [24].

Statistics (NCES) reported that $48 \%$ of teachers transferred to another location of school and 39\% switched professions because their workplace is lacking of management facilities and is poor in terms of comfort level. Improving the school facilities and environmental condition may also give more benefits to the teachers or supporting staff by increasing their morale and reduce absenteeism and turnover, indirectly leads to student achievement [18].

The implications for health, teaching and learning process of students who spend time in the school building are based on the decision about the location a school is built, design of building structure, method of construction, the facilities installed and school policies, and programs that are implemented. To ensure the functioning of all school facilities such as air conditioning, fans, chairs and tables, lighting and others, the school facility management department has to be ready with a monthly record for assessing the facilities' condition in a proper system. Any updating of facility items and maintenance or repair normally will be recorded by following the standards and guideline [34].

However, the poor condition of school building performance is not only caused by unmaintained facilities but also critical building defects that always affect the building performance and the teaching and learning process. According to the building condition assessment conducted in the school building as recorded, a total of 4,275 defects were identified at Kuching, which include components of walls, floor, doors, fittings, windows, and ceiling; however, from the assessment, school building cracks has the highest percentage of defects which is about $16.2 \%$. Large number of school building cracks is due to functionality in the walls and floor as a major component of a building itself [1]. 
The success of teaching and learning process in the school environment is based on the comforts level and building performance itself. School building defects always disturb the condition of comfort during the teaching and learning process, by which effectiveness of school building performance with well-organized and efficient lesson planning preparation will help a teacher to teach and the students have more concentration to learn. Failure to maintain the school building from any defects will not be conducive for smooth teaching and learning process hence resulting frustration among students [35].

According to the U.S. Department [39] of Education, federal, state and local government spend more than $\$ 50$ billion per year to build and renovate public schools building including various categories of damage and defects especially in school facility and building structure. Likely, the problem of school building defects is not taken too seriously because the benefits may be focused on nonacademic outcomes like student health and safety [8]. In contrast, this will affect the school reputation directly and indirectly for the school's long-term building performance [11].

Building defects derived several bad consequences in ensuring high quality of school building to produce high impact on teaching and learning environment. The importance to know about the soul of education, which is good infrastructure, is truly at the base of quality of education and good building condition where the teaching and learning process will produce perfect student achievement [18].

The purpose of the study presented here is to evaluate the effectiveness of teaching and learning by analyzing the common defects that contribute to the school building. Major defects involved in school buildings will be identified in this study. Besides, this study aimed to analyze the impact of school building defects to the teaching and learning environment.

\section{LITERATURE REVIEW}

The manuscript article should be written in English in the font of Times New Roman, which includes the following: abstract, introduction, literature review, objectives, research methodology, theory, testing and analysis, results and discussions, conclusion, acknowledgement and references. Manuscript should be prepared via the Microsoft Word processor. Do include the duplicate hardcopy and softcopy to the editor.

\section{School Building Defects}

Building defects means the material, component or finishes which fail to meet its expected building performance criteria. There are many problems to relate with building defects such as failures in the function and occupant discomforts that reduce the efficiency of building performance [30] Roman.

\section{Teaching and Learning Environment}

Teaching and learning activities need the basic learning environment. Building an excellent learning environment means considering both perspectives of psychologists and instructional lists, which help teaching process to be more

productive to the learners. Learning environment reflects the various physical aspects such as locations, cultures, and contexts where the students have the capability to learn. Students are encouraged for wide learning that result in more experience on learning; it is also more accurate and effective that focuses not only on traditional learning. The teaching and learning environment could give an impact to students' behaviour, attitude, and achievement [7].

\section{Common Type of Building Defects}

Generally, several types of building defects that are usually involved in building elements include walls, tiles, doors, windows, ceilings, and roofs [3]. Besides, building defects frequently found in building elements will be discussed which include wall cracks, dampness, peeling paint, attack of insects or termites, timber decay, fungal or small plant attack, defective plaster rendering, roof defects, and erosion of mortar joint.

\section{Table 1. List of common buildings defects with the related researcher}

\begin{tabular}{|c|c|c|}
\hline $\begin{array}{c}\text { No } \\
\text {. }\end{array}$ & $\begin{array}{c}\text { Common } \\
\text { Building Defects }\end{array}$ & Researcher \\
\hline 1. & Crack on walls & $\begin{array}{l}\text { (Ahzahar et al., 2011), } \\
\text { (Olanrewaju 2012) }\end{array}$ \\
\hline 2. & Peeling paint & $\begin{array}{l}\text { (NIOSH 2012), (Whiteley } \\
\text { 2007) }\end{array}$ \\
\hline 3. & Dampness & $\begin{array}{l}\text { (Bakri \& Mydin 2014), } \\
\text { (NIOSH 2012), (Hollis }\end{array}$ \\
\hline 4. & Timber decay & $\begin{array}{l}\text { (Ishak et al. 2009), (Barry } \\
\text { 2002) }\end{array}$ \\
\hline 5. & $\begin{array}{l}\text { Insect or } \\
\text { termites attack }\end{array}$ & $\begin{array}{l}\text { (Ahmad 2004), (Bakri \& } \\
\text { Mydin 2014). }\end{array}$ \\
\hline 6. & $\begin{array}{l}\text { Fungal and } \\
\text { small plant } \\
\text { attack }\end{array}$ & (Bakri \& Mydin 2014). \\
\hline 7. & $\begin{array}{l}\text { Defective plaster } \\
\text { rendering }\end{array}$ & (Ahmad 2004) \\
\hline 8. & Roof defect & (Bakri \& Mydin 2014) \\
\hline 9. & $\begin{array}{l}\text { Erosion of } \\
\text { mortar joint }\end{array}$ & (Md.Kasim 2009) \\
\hline
\end{tabular}

\section{Impact of School Building Defects on Teaching and Learning Environment}

School building is an asset of the country that ensures early level of education process. To maintain the value of assets, it must be managed by the professionals or related technicians. However the maintenance management system in Malaysia still needs further improvement. Furthermore, not all school buildings have frequent school building maintenance due to insufficient guidelines of the proper process of maintaining. Lack of managing and maintaining the performance of school building and facilities can affect serious school building defects that disturb the teaching and learning environment. 
The following are several impacts of school building defects on the teaching and learning environment.

Table 2. List of impacts school building defects to the teaching and learning environment with the related researcher

\begin{tabular}{|c|c|c|}
\hline No. & $\begin{array}{c}\text { Impact of School } \\
\text { Building Defects to } \\
\text { Teaching and } \\
\text { Learning } \\
\text { Environment }\end{array}$ & Researcher \\
\hline 1. & Loss concentration & $\begin{array}{l}\text { (Sebastian \& } \\
\text { Allensworth 2012), (G. } \\
\text { Sang et al. 2010), } \\
\text { (Reupert \& Woodcock } \\
\text { 2010) }\end{array}$ \\
\hline 2. & $\begin{array}{l}\text { Reduced } \\
\text { achievement }\end{array}$ & $\begin{array}{l}\text { (Lanham 1999), } \\
\text { (Tracie et al. 2013) }\end{array}$ \\
\hline 3. & $\begin{array}{l}\text { Unhealthy } \\
\text { condition }\end{array}$ & $\begin{array}{l}\text { (Baker \& Bernstein } \\
\text { 2012) }\end{array}$ \\
\hline 4. & Safety issues & $\begin{array}{l}\text { Hassanain \& Iftikhar } \\
\text { 2015), (Chuen 2008) }\end{array}$ \\
\hline 5. & Student attendance & $\begin{array}{l}\text { (Traphagan 2010), } \\
\text { (Lewis 2001) }\end{array}$ \\
\hline
\end{tabular}

\section{METHODOLOGY}

The methodology of this study focused on two phases. Firstly, a comprehensive article review was carried out to find the main issues of school building defects and the impacts on students learning environment. Secondly, this study has the approach of quantitative data that were collected through the distribution of questionnaire to the respondents. The questionnaire development consists of Section A: Building Defects and Section B: Effects on Teaching and Learning by which the respondents need to select the choices given These respondents spend most of their time at the school building for daily school session from 7 am to $4 \mathrm{pm}$, except for the students who are only at school until $2.30 \mathrm{pm}$. The respective codes, categories of respondents involved, and response rates are reported in Table 3. The questionnaire consists of two (2) parts: school building defects and effects of school building defects to teaching and learning environment. The scope of study was based on two (2) secondary school buildings in Selangor, Malaysia that are relevant to the issues of defects. Besides, interview session have been conducted with ten (10) teachers as experienced participants to show the significant relationship between building defects and its effect to teaching and learning activities.

The data collected were analyzed using the software of Statistical Package Social Science (SPSS) version 24 and Microsoft Excel window 2016. To identify the common defects in the school building, 9 items were analyzed and for the effects of school building defects on learning environment, 5 items were involved.

The 9 items of common defects were known as (CW) cracks on wall, (PP) peeling paint, (DP) dampness, (TC) timber decay, (IA) insect or termite attack, (FA) fungal and small plan attack, (DR) defective plaster rendering, (RD) roof defect, and (EM) erosion of mortar joint as shown in Table 1. However, in Table 2 there are 5 items of effects to students' learning environment consists of (LC) less concentration, (RA) reduce achievement, (UC) unhealthy condition, (SI) safety issues, and (SA) student attendance.

Table 3. Distribution of Questionnaire to Respondents

\begin{tabular}{|c|c|c|c|c|}
\hline $\begin{array}{c}\text { Code } \\
\text { of } \\
\text { Scho } \\
\text { ol }\end{array}$ & $\begin{array}{l}\text { Category } \\
\text { of } \\
\text { Responden } \\
\text { ts }\end{array}$ & $\begin{array}{c}\text { No. of } \\
\text { Questionnai } \\
\text { re } \\
\text { Distributed }\end{array}$ & $\begin{array}{c}\text { No. of } \\
\text { Responden } \\
\text { ts }\end{array}$ & $\begin{array}{c}\text { Respon } \\
\text { se Rate } \\
(\%)\end{array}$ \\
\hline \multirow{3}{*}{$\begin{array}{l}\text { BEA } \\
4628\end{array}$} & Student & 22 & 18 & 81.82 \\
\hline & Teacher & 9 & 5 & 55.56 \\
\hline & $\begin{array}{l}\text { Supportive } \\
\text { staff }\end{array}$ & 8 & 6 & 75 \\
\hline \multirow{4}{*}{$\begin{array}{l}\text { BEA } \\
4605\end{array}$} & Student & 14 & 12 & 85.71 \\
\hline & Teacher & 8 & 5 & 62.5 \\
\hline & $\begin{array}{l}\text { Supportive } \\
\text { staff }\end{array}$ & 7 & 4 & 57.14 \\
\hline & & 68 & 50 & 73.53 \\
\hline
\end{tabular}

\section{Descriptive Statistics Analysis}

Analysis of descriptive statistics was applied in the quantitative data where representation of a sample size with given data set is described into table, picture, or various types of diagram such as pie chart, bar chart, and line chart. In this study, the descriptive statistics analysis was defined by mean and the variables were classified into ranking and chart which included measurement scales of interval, ordinal, and nominal [21].

Furthermore, by using computer application SPSS, it may also evaluate the value of coefficient alpha reliability $(\alpha)$ to show the level of variables' reliability in this study.

Hypothesis testing considers the significance level of the correlation coefficient (r). The confident level of this testing was stated at $95 \%$ with two tailed-test. The null hypothesis for the test is as follows:

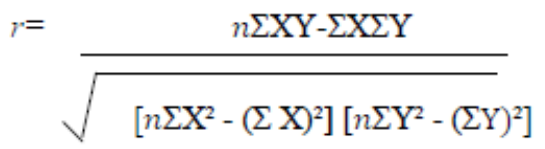

The correlation that ranges between -1 (negative relationship) and +1 (positive relationship) for $r$ output ($1<\mathrm{r}<+1$ ) for this analysis is defined as a perfect correlation between two variables. In this study, Pearson's correlation is used to compare the relationship between two variables which are school building defects and their effects on teaching and learning.

\section{Published By:}

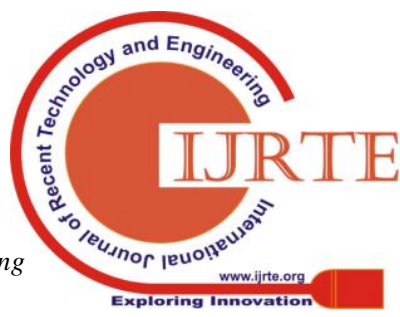




\section{Pearson's Correlation Analysis}

Correlation is considered as relationship between two variables in $\mathrm{X}$-axis and $\mathrm{Y}$-axis, where Pearson's productmoment correlation coefficient ( $r$ ) has been used for the statistical analysis in this study because it is simple to conduct and easy for understanding of the concept. Pearson's correlation analysis can be determined by the formula as follows:

H0: $p=0$, which means no relationship between the compared variables

$\mathrm{H} 1: \mathrm{p}=0$, which means significant relationship between the compared variables based on

$$
t=\frac{r}{\sqrt{\frac{1-r^{2}}{n-2}}}
$$

where, $r=$ correlation coefficient and $n=$ sample size.

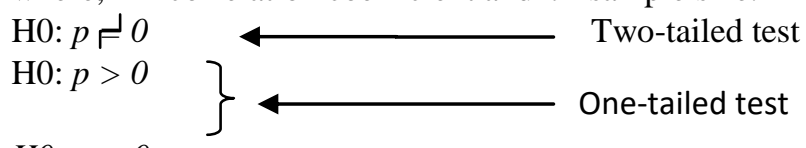

HO: $p<0$

\section{RESULTS AND DISCUSSION}

\section{Descriptive statistics and reliability analysis of school building defects}

Based on Table 4, peeling paint (PP) with mean scale of $(0.22)$ is ranked as the highest defect in the school building. Dampness (DP), with mean scale of $(0.21)$ is ranked as the second highest defect involved in the selected school building. However, cracking wall $(\mathrm{CW})$, mean scale of (0.20) is ranked as third highest defect that participates in the school building. The other defects in school building are followed by roof defect (RD), defective plaster rendering (DR), timber decay (TC), fungal attack (FA), insect or termite attack (IA), and erosion mortar (EM) with the mean scales of (0.13), (0.09), (0.04), (0.04), and (0.03).

To evaluate the consistency, reliability analysis was conducted on element of school building defects identified in the study (Table 4). According to [3], there are nine (9) defects identified including peeling paint (PP), cracking wall $(\mathrm{CW})$, erosion of mortar joint (EM), roof defect (RD), defective plaster rendering (DR), timber decay (TC), dampness (DP), fungal attack (FA), and insect or termite attack (IA). The result showed that all defects in school building in this study were reliable, hence, coefficient alpha reliability of (0.70). The reason of reliability may be due to cause of these defects that is able to affect the teaching and learning in the school environment. According to Guttmann 1945 [12] or Cronbach 1951[9] , they mentioned the values of alpha of less than 0.67 (poor), 0.67-0.80 (fair), 0.81-0.90 (good), 0.91-0.94 (very good), and more than 0.94 (excellent). This shows that the value of coefficient alpha (0.70) of school building defects was in the fair criterion category (0.67-0.80).
Table 4. Scale of items defects in mean, rank, and

\begin{tabular}{|c|c|c|c|c|}
\hline $\begin{array}{c}\text { Type of Defects in } \\
\text { School Building }\end{array}$ & Item & Mean & $\begin{array}{l}\text { Ran } \\
k\end{array}$ & $\alpha$-value \\
\hline Cracking Wall & $C W$ & 0.20 & 3 & \multirow{10}{*}{0.70} \\
\hline Peeling Paint & $P P$ & 0.22 & 1 & \\
\hline Dampness & $D P$ & 0.21 & 2 & \\
\hline Timber Decay & $T C$ & 0.04 & 6 & \\
\hline Insect /Termite & $I A$ & 0.03 & 7 & \\
\hline Fungal Attack & $F A$ & 0.04 & 6 & \\
\hline Defective Plaster & $D R$ & 0.09 & 5 & \\
\hline Rendering & & & & \\
\hline Roof Defect & $R D$ & 0.13 & 4 & \\
\hline $\begin{array}{l}\text { Erosion of Mortar } \\
\text { Joint }\end{array}$ & $E M$ & 0.02 & 8 & \\
\hline
\end{tabular}
coefficient alpha reliability

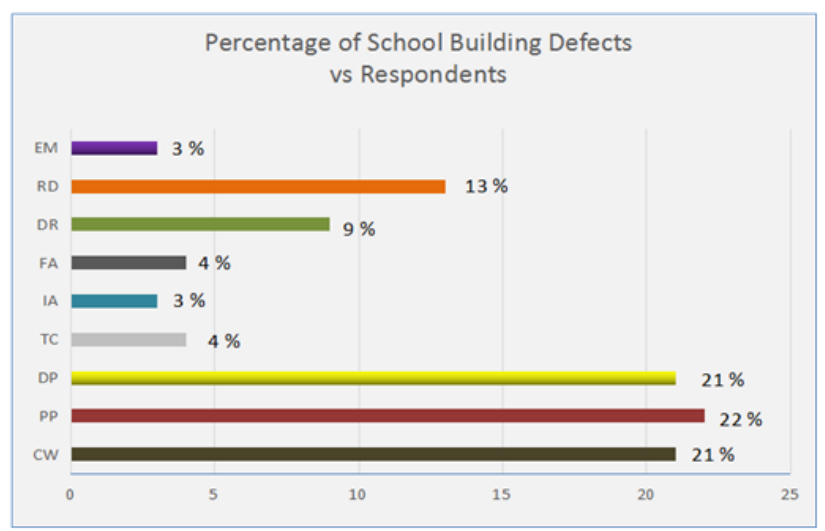

Fig. 1 Percentage of School Building Defects and Respondents

We can see in Figure 1 where the percentage of school building defects has shown peeling paint (PP) with $22 \%$ as the highest percentage in respondents' awareness and followed by insect attack (IA) and erosion mortar (EM) with $3 \%$ as the lowest percentage of response in this survey. However, major defects may be illustrated by respondents' response which also consists of cracking wall (CW), dampness (DP), and roof defects (RD). Due to the building that aged, peeling paint (PP) normally will happen because of the climate and activities of the occupants in the school building. Other than that, ignorance to the quality of paint selection may also affect the peeling paint [26]. However, insect or termite attack (IA) is very rarely involved in the school building because the main building structure such as column, beam, and floor are constructed from concrete, which reduces the possibility of insect or termite attacks. The picture as below shows the common defects involved in this study at school buildings, which can be seen in figure 2 (a) peeling paint, 2 (b) timber decay and insect or termite attack, 2 (c) dampness and fungal Attack and 2 (d) cracking wall and defective plaster rendering.

The findings in Table 4 and Figure 1 show that based on types of defects occurred in the school building, 
the peeling paint is ranked as the main defect by which peeling paint that usually happens in the school building is due to low quality of paint applied at the wall which may reduce the long-lasting of the painting. Next, the rare defect is erosion of mortar joint because nowadays, the school building is constructed by concrete structure with a standard specification by the authorities. Other than that, there is no natural disaster such as earthquake that may damage the building structure and give a negative impact on mortar joints [29]. Defects that is ranked as second is dampness and then followed by cracking wall, roof defect, defective plaster rendering, fungal attack, timber decay, and insect or termite attack.

\section{Descriptive statistics and reliability analysis of effects on teaching learning}

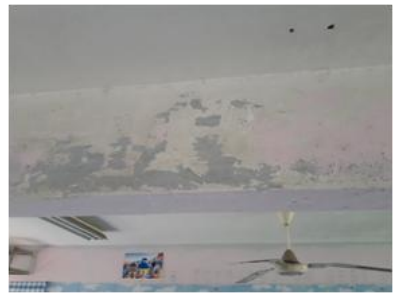

(a)

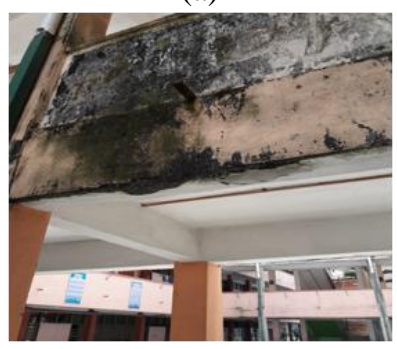

(c)

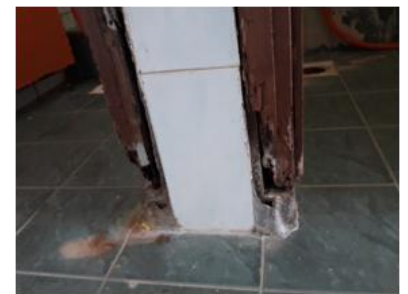

(b)

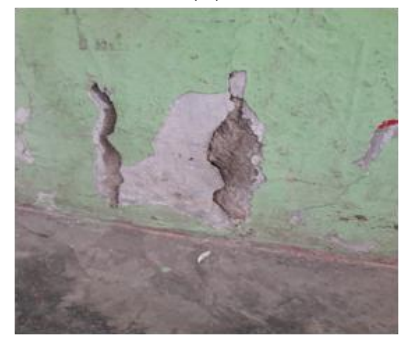

(d)
Fig. 2 Building Defects in School Buildings

The effect of school building defects on teaching and learning environment was analyzed as shown in Table 5. Less concentration, LC (0.31) is the most critical effect that influenced teaching and learning if school building defects always happen in the school buildings especially in the major areas of school such as classroom, laboratory, and library. Besides, $70 \%$ of interview participants realized that poor school building performance especially related with defects were give an impact in students' concentration during the teaching and learning process. Basically, the students' concentration is affected if their classroom involved with many defects such as dampness, fungal attack and floor defects. Safety issues, SI (0.30) is ranked as the second effect on building operation mainly to students and teachers who spend more hours in the school buildings. However, the analysis is followed by student attendance, SA (0.14), unhealthy condition, UC (0.13), and reduced achievement, RA (0.12) which is grouped in less factors affecting the teaching learning environment. There are, 55\% of interview participants were agreed that school building defects especially involving the classroom area is affected health and safety of students, where unhealthy condition is encourage them to skip the class and directly reduced their achievement.
The effects on teaching and learning factors were tested by reliability analysis that is determined by coefficient alpha reliability. The value of coefficient alpha (0.73) was fairly reliable in this study that the school building defects actually may provide a profound effect on teaching and learning in schools.

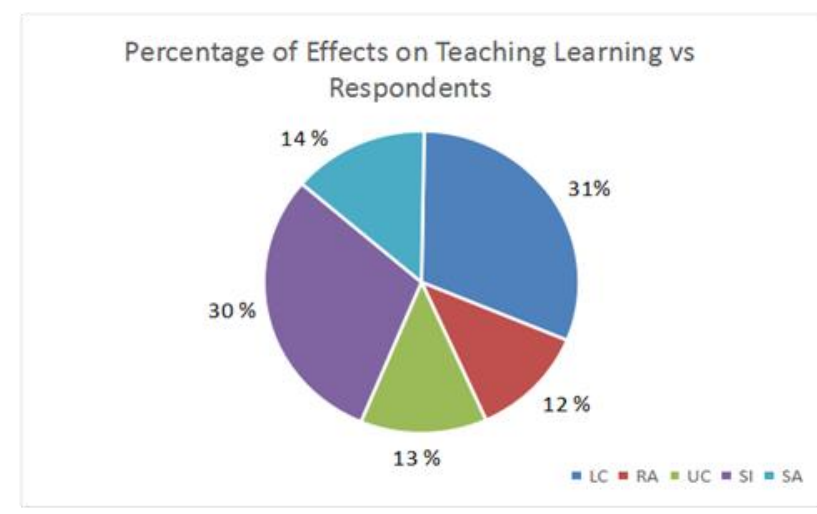

Fig. 3 Percentage of Effects on Teaching Learning Due to Building Defects

As shown in Figure 3 above, we can see that the building defect that may affect teaching and learning during the school session is mainly loss of concentration because the poor condition of school building performance may reduce the students' focus during the learning process [10]. Safety issues due to school building defects are normally dangerous to the students in the school environment for example building cracks and timber decay [19]. Unhealthy condition is usually due to fungal attack and dampness in the area of classroom environment [36]. Students' attendance will be affected if the serious and critical conditions of defects around the building require some areas in the school to close.

Table 5. Scale of items effects on teaching and learning in mean, rank, and coefficient alpha reliability

\begin{tabular}{lllll}
\hline \multicolumn{1}{c}{$\begin{array}{c}\text { Effect of School } \\
\text { Building Defects }\end{array}$} & Item & Mean & $\begin{array}{c}\text { Ran } \\
\mathrm{k}\end{array}$ & $\begin{array}{c}\alpha- \\
\text { value }\end{array}$ \\
\hline Loss of Concentration & LC & 0.31 & 1 & \\
Reduced Achievement & RA & 0.12 & 5 & \\
Unhealthy Condition & UC & 0.13 & 4 & 0.73 \\
Safety Issues & SI & 0.30 & 2 & \\
Student Attendance & SA & 0.14 & 3 & \\
\hline
\end{tabular}

Defects in school building are based on the findings (Table 5) which show that the main effects on teaching and learning are loss of concentration by which the reason is that defects may reduce the students' focus during lessons. Next is safety issue, student attendance, unhealthy condition, and lastly reduced student achievement. Therefore, learning environment needs to be comfortable and conducive especially for the students and also other occupants such as the school principal and teachers. 
Based on the result above, it was clearly determined that school building defects will normally affect the students' concentration during the teaching and learning process especially in the classroom where they need to be more focused as compared to the outside activities such as physical and sport. Therefore, poor school building performance may reduce the students' concentration during the learning process and may also involve safety issues when the schools building defects become harmful to the students and other users.

\section{Correlation analysis between defects and effects on teaching and learning}

Pearson's correlation analysis is used to investigate the relationship between school building defects and their effects on teaching and learning session. Meanwhile, the result of correlation in Table 6 indicates the level of a positive statistical relationship between school building defects and their effects to teaching and learning among students. The defects include peeling paint (PP), cracking wall $(\mathrm{CW})$, erosion of mortar joint $(\mathrm{EM})$, roof defect (RD), defective plaster rendering (DR), timber decay (TC), dampness (DP), fungal attack (FA), and insect or termite attack (IA). Next, there are five (5) effects on the teaching and learning process which include less concentration (LC), safety issues (SI), student attendance (SA), reduced achievement (RA), and unhealthy condition (UC). In the correlation analysis, the significant level is at $p<0.01$. Based on Table 3 below, a positive correlation exists at $p<0.01$ which involved cracking wall (CW), dampness (DP), and roof defect (RD) that have a significant relationship with loss concentration (LC), reduced achievement (RA), unhealthy condition (UC), safety issue (SI), and student attendance (SA). Other than that, timber decay (TC) has a relationship with loss of concentration (LC), reduced achievement (RA), and unhealthy condition (UC); however, insect or termite attack (IA) with reduced achievement (RA), unhealthy condition (UC), safety issue (SI), and student attendance (SA). Fungal attack (FA) only has a positive relationship with unhealthy condition (UC). Defective rendering (DR) has a significant relationship with loss of concentration (LC) during the teaching and learning process. Erosion of mortar (EM) has a positive relationship with reduced achievement (RA) and unhealthy condition (UC).

Besides, there is a positive relationship with significant $\mathrm{p}<0.05$ between peeling paint (PP) and student attendance (SA) and also unhealthy condition (UC), fungal attack (FA), and less concentration (LC). Moreover, there is a relationship between erosion of mortar (EM) and reduced achievement (RA), safety issue (SI), and also student attendance (SA).
Table 6. Descriptive statistic (Pearson's correlation of school building defect and their effects on teaching and learning)

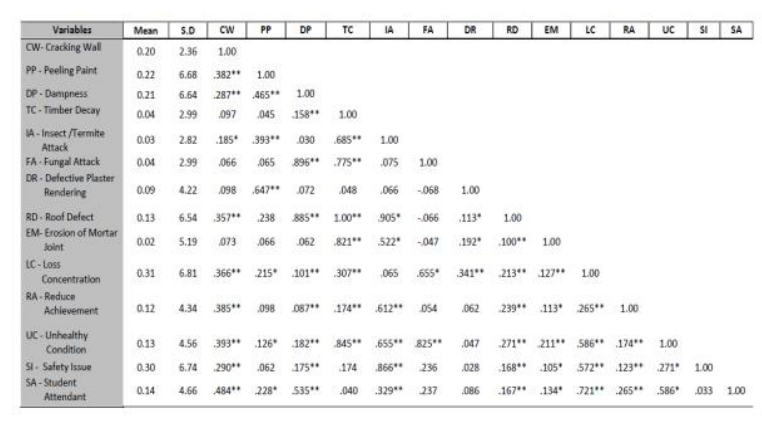

** Significant correlation at 0.01 level (2-tailed)

Significant correlation at 0.05 level (2-tailed)

S.D - Standard Deviation

The findings have shown that building defects such as cracking of the wall may affect the students' concentration during the teaching and learning session and it will also encourage occupants to be cognizant of safety issues because the wall as the main structure should be in a stable condition. Next, students is highly possible of losing concentration if the wall cracking is not repaired immediately and normally, the school management will give the instructions to close the specific area if it is not safe in terms of structure or other facilities. Other than that, peeling paint in the wall structure may influence the students to be absent (not attend) in the school session, for example, if the wall in the classroom is not properly painted or having peeling paint which makes the environment in the classroom to not be interesting or fail to influence the students' learning process. The school environment may affect the students' discipline (attitude and behaviour) while student attendance is categorized as an aspect of student discipline [24]. Insect or termite attacks become a safety issue to school occupants by which if the insects of termites seriously attack, it may damage the school building structure or furniture such as tables and chairs.

\section{CONCLUSION}

In this century, school building is important to ensure the effectiveness of teaching and learning process. Besides, the formal schooling system should provide proper school building at least for the basic usage. However, maintenance of school building needs to be managed periodically to avoid from any serious defects to occur at the main area of school building for instance classroom, management office, library, canteen, toilet, and laboratory. Sometimes, immediate maintenance or repair is significant for school buildings especially for the ones that have been long established or old school buildings, which normally need frequent maintenance or repair.

School building performance may give an impact on teaching and learning; moreover, if the school building is always interesting and safe, it will be able to influence 
students' attendance, achievement, and concentration during the learning process. School buildings should also be an aspect for students to show better disciplines while the teachers also feel motivated to attend and educate the students in school hence reducing the teachers' duty to manage the school building that get involved with defects regularly. School buildings should be functioning with high satisfaction of occupants' to make them feel more motivated and so that their achievement increases gradually. Poor school building performance is usually expressed by the defects in the building, whereas school building should focus on the health and safety environment for the students to gain knowledge and information during the learning process. Concentration of students in the classroom will also be affected if the critical school building defects happen and then also affect their interest to attend school. This study does not imply that school buildings have to be setup perfectly before functioning; however, they need to consider some advantages and disadvantages of better school buildings. There are more advantages of good school building performance such as high quality of student behaviour and attitude during the school session. However, there are also disadvantages of this due to high expenditure and cost for any school building maintenance and repair that takes place in the school buildings. The conducive environment is probably not focusing on classroom but for the entire school building as well.

Generally, in order to perform better school buildings with lack of defects, the school management must systematically manage the school buildings by proper documentation, maintenance schedule, supportive staff, and basic tools or equipment for any emergency, or simple repairing of building elements such as lamp and fan replacement in the school building that may reduce the cost of maintenance or repair service.

In conclusion, satisfactory school buildings may encourage the effectiveness of learning environment which is relevant for students or teachers in the teaching and learning process. Therefore, by improving the condition of school buildings, it will lower the risk of defects and provide an optimum learning environment for all students and other users.

\section{ACKNOWLEDGMENT}

The authors would like to express their heartiest thanks to the Ministry of Education Malaysia, Universiti Kebangsaan Malaysia, Universiti Sains Malaysia and Research Grant Scheme (Geran Galakan Penyelidik Muda): GGPM-2017058 for supporting this paper. The credit also goes to various organizations that have assisted towards the success of this paper.

\section{REFERENCES}

1. A Ghafar Ahmad. 2004. "Understanding Common Building Defects",Architec Magazine, 16 (1): 19-21.

2. A.H Samah, N.M Tawil Mahli, A.I. Che Ani, M. . A. R. 2014. "Building Condition Assessment Using Condition Survey Protocol matrix: A Case of School Building", Research Journal of Applied Science, 9 (9): 565-572.
3. Ahzahar, N., Karim, N. A., Hassan, S. H. \& Eman, J. 2011."A Study of Contribution Factors to Building Failures and Defects in Construction Industry", Procedia Engineering The 2 nd International Building Control Conference 2011, Procedia Engineering, 20: 249-255

4. Bakri, N. N. O. \& Mydin, M. A. O. 2014. "General Building Defects: Causes, Symptoms and Remedial Work", European Journal of Technology and Design, 3 (1): 4-17.

5. Baker, L. \& Bernstein, H. 2012. "The Impact of School Buildings on Student Health and Performance". Mc Graw Hill Research Foundation : 1-36.

6. Barry A.Richardson. 2002. Defects and Deterioration In Buildings, 2nd Edition. Taylor \& Francis Group.

7. Chan, T. C. \& Chan, T. C. 2009. "Do portable classrooms impact teaching and learning", Journal of Educational Administration, 47 (3): 290-304

8. Chance J. T., Shannon M.C. 2015. "Enhancing Building Performance and Environmental Learning": Hampton University, USA: 54-73..

9. Cronbach, L. J. 1951. "Coefficient alpha and the internal structure of tests". Psychometrika, 16: 297-334.

10. Giallo, R. \& Little, E. 2003. "Classroom Behaviour Problems: The Relationship between Preparedness, Classroom Experiences, and Selfefficacy in Graduate and Student Teachers". Australian Journal Of Educational \& Development Psychology, 3: 21-34.

11. Graça, B., Jorge, F., Marques, M. \& Escolar, P. 2011. "High performance school bu i ld i ngs in Portugal : a life cycle perspective". Deputy Director, Sustainability Department Parque Escolar, E.P.E, (October 2009).

12. Guttman, L. 1945. "A basis for analyzing test-retest reliability", Psychometrika, $10: 255-282$.

13. Hampshire, N. 2016. "Public School Enrollment". The Condition of Education 2016: 14-15.

14. Hassanain, M.A.Iftikhar, A. 2015. Framework model for postoccupancy evaluation of school facilities. Structural Survey, 33 (4-5): 322-336.

15. Hollis, M. (006. "Survey of surveys", Emerald Group Publishing Limited, 17(3) :138-142.

16. Hopland, A. O. 2012. "School building conditions and student achievements: Norwegian evidence Department of Economics". Department of Economics, Norwegian University of Science and Technology Norway : 2 .

17. Hopland, A. O. 2013. "School Facilities and Student Achievement in Industrial Countries: Evidence from the TIMS", Canadian Center of Science and Education, 6 (3): 162-171.

18. Hopland, A. O. 2015. "How related are technical and subjective measures of building conditions: The case of Norwegian public schools", Department of Business and Management Science, NHH, Norwegian School of Economics, Bergen, Norway, 32 (5/6): 295-306.

19. Kamsari, S. A. 2015. "Unsafe School Building". Utusan Malaysia, 11 March 2015, pp. 3-4.

20. Keith, G. 1987. "Dampness in Buildings". Emerald Group Publishing Limited,1 (2) : 150-154.

21. Krippendorff, K. H. 2004. Content Analysis: An Introduction to Its Methodology.2nd Edition.

22. Lanham, J. W. 1999. Relating Building And Classroom Conditions To Student Achievement in Virginia's Elementary Schools. Blacksburg, Virginia,.

23. Lewis, R. 2001. "Classroom discipline and student responsibility: the students' view", Teaching and Teacher Education, 17 (1) : 307-319.

24. Lumpkin, R. B., Jr, R. T. G., Hope, W. C. \& Lutfi, G. 2014. "Code Compliant School Buildings Boost Student Achievement", Sage Open, (October-December): 1-8.

25. Ministry of Education Malaysia, 2012. National Education Policy. (Bahagian Perancangan dan Penyelidikan Dasar Pendidikan, Ed.) 3rd Edition. Putajaya: Giga Wise Network Sdn Bhd.

26. Mydin, M. A. O., Salim, N. A. A., Tan, S. W., Tawil, N. M. \& Ulang, N. 2014. "Assessment of Significant Causes to School Building Defects", Emerging Technology for Sustainable Development Congress (ETSDC 2014), 3: 1-7. 
27. NIOSH. 2012. Preventing Occupational Respiratory Disease from Exposures Caused by Dampness in Office Buildings, Schools, and Other Nonindustrial Buildings. Department Of Health And Human Services Centers for Disease Control and Prevention National Institute for Occupational Safety and Health: 28.

28. Nor Haniza Ishak, Zuraini Md Ali, Yacob Omar, H. A. H. 2000. Case Studies on Timber Defects of Selected Traditional Houses in Malacca. Department of Building Survey ing, Faculty of the Built Environment, University of Malaya: 81-90.

29. Nur Diyana Binti Md.Kasim. 2009. "Building Defect: Case Study at Taman Seri Indah, Pulau Pinang". Faculty of Civil Engineering \& Earth Resources Universiti Malaysia Pahang : 25.

30. Olanrewaju, A. A. L. 2012. "Quantitative analysis of defects in university buildings: user perspective". Emerald Group Publishing Limited, 2 (2): 167-181.

31. Reupert, A. \& Woodcock, S. 2010. "Success and near misses : Preservice teachers' use, confidence and success in various classroom management strategies", Teaching and Teacher Education, 26 (6) : 1261-1268.

32. Sebastian, J. \& Allensworth, E. 2012. "Educational Administration Quarterly". Educational Administration Quarterly, 48 (4): 626-663.

33. Selvadurai, S., Liu, O. P., Radzi, M. M., Hoon, O. P. \& Tee, O. P. 2015. "Debating education for nation building in Malaysia: National school persistence or vernacular school resistance", Malaysian Journal of Society and Space, 13 (13): 14-23.

34. Sherry Everett Jones, Alisa M. Smith, R. A. A. M. W. 2012. "Results from the School Health Policies and Practices Study", U.S. Department of Health and Human Services Centers for Disease Control and Prevention: 9 .

35. Suleman Qaiser and Ishtiaq Hussain. 2014. "Effects of Classroom Physical Environment on the Academic Achievement Scores of Secondary School Students in Kohat Division , Pakistan". Institute of Education \& Research, Kohat University of Science \& Technology, Khyber Pakhtunkhwa, (Pakistan), 4 ( 1) : 71-82.

36. Tan Wei Chuen. 2008. " Problem of Building Defects". Ministry of Higher Education, 255: pp, 1-5.

37. Tracie, A. D. Y., Stephanie, D. B., Melissa, D., Young-jones, A. D., Burt, T. D., Dixon, S. \& Hawthorne, M. J. 2013. "Academic advising: does it really impact student success ", Quality Assurance in Education, 21 (1) : 7-19.

38. Traphagan, T. 2010. "Impact of class lecture webcasting on attendance and learning Springer Link", Educational Technology Research and Development, 58 (1): 19-37.

39. United States of America Department of Education. 2013. U.S. Department of Education Strategic Plan for Fiscal Years 2014 - 2018. Department of Education, U.S

40. Whiteley, P. 2007. Trends in paints and finishes for buildings. Emerald Group Publishing Limited, December: 4-8. 